\title{
MAGEA3 wt Allele
}

National Cancer Institute

\section{Source}

National Cancer Institute. MAGEA3 wt Allele. NCI Thesaurus. Code C54307.

Human MAGEA3 wild-type allele is located in the vicinity of Xq28 and is approximately 4 $\mathrm{kb}$ in length. This allele, which encodes melanoma-associated antigen 3 protein, plays a role in the regulation of tumor cell recognition by killer $T$ lymphocytes and may be involved in embryonic development. 